\title{
Voter turnout at the national level in Poland - selected aspects ${ }^{1}$
}

\begin{abstract}
The article addresses the issue of voter turnout at the national level in Poland in 1990-2019. In particular, the author focused on 2019, when the turnout in parliamentary elections was the highest throughout the period under analysis. The aim of the study is to determine the reasons for this increase in the electoral activity of Polish citizens. The analysis leads to the conclusion that after the Law and Justice party took power in 2015, significant modifications of the social system, including the political system, ensued, thereby altering selected features of the electoral situation and raising the level of political emotions. The outcome involved a significant increase in voter turnout in 2019, when the elections to the European Parliament, as well as to the Polish parliament (the Sejm and Senate) were held. The study employs the following methods: analysis and criticism of literature (sources), the systemic method, and statistical methods.
\end{abstract}

Key words: democracy, illiberal democracy, political participation, elections, voter turnout

\section{Introductory remarks}

- lections enable the citizens of modern democracies to decide on the personal composition of elected state bodies, and - looking from a broader perspective - make it possible to influence political decisions. The election procedure is an example of conventional political participation, which "is understood as an activity compliant with the order established by the constitution and falling within the framework of democratic instruments. Most often it is associated with elections of the authorities (at various levels) and the legitimate influence of individuals on the selection of actions taken by politicians" (Skarżyńska, 2002, s. 29).

The article addresses the issue of voter turnout in Poland, which can be defined as "the actual number of people voting in the election (single or in selected years) in relation to the total number of people eligible to vote, usually expressed as a percentage" (Sokala, Michalak, Uziębło, 2013, p. 58). Pursuant to the Electoral Code, "the number of valid voting ballots constitutes the number of people who voted in a given constituency" (Ustawa, Art. 74). Thus, according to the legal definition, voter turnout in Poland is determined on the basis of the number of valid voting ballots.

While in classical democracy political life relied on people's assemblies, modern democracies are based on the functioning of elected parliaments. That is why the is-

${ }^{1}$ This article was prepared under the project "E-voting as an alternative voting procedure in state elections. Experiences of selected states and the prospects for e-voting being implemented in Poland" [E-voting jako alternatywna procedura głosowania w elekcjach państwowych. Doświadczenia wybranych państw a perspektywy wdrożenia e-głosowania w Polsce] - financed by the National Science Center Poland (NCN) - OPUS, UMO-2014/15/B/HS5/01358. 
sues related to the electoral process are crucial for democratic states and arouse considerable interest among the public, political elites, the media, scholars representing various academic disciplines, and others (Rachwal, 2017a, pp. 51-86). It should be indicated here that the considerations concern voting conducted at the national level in the elections of the President of the Republic of Poland, elections to the Polish parliament (the lower and the upper chambers: the Sejm and Senate), and to the European Parliament.

The study focuses on two aspects of the issue of voter turnout, namely it indicates the level of public participation in electoral procedures, and attempts to explain the reasons for the electoral activity and passivity of Poles. The study was inspired by the increase in voter turnout in the 2019 elections, a trend that had already been observed in the local elections held in 2018. The purpose of the study is to identify the determinants of this situation. What are the reasons behind this clear increase in the electoral activity of Poles? An attempt to handle the research problem thus formulated determined the successive stages of the academic inquiry, the outcomes of which are presented in this article.

The timeframe of this brief study spans the period 1990-2019. The beginning of this period is marked by the presidential election in 1990, the first fully free national election during the political transformation in Poland. The final date is determined with a view to presenting the most current situation. ${ }^{2}$

The theoretical foundations for this paper have been provided by four sources: the monograph by Krystyna Skarżyńska Człowiek a polityka. Zarys psychologii politycznej [Man versus politics. An outline of the psychology of politics] (Warszawa 2005), two articles by Beata Pająk-Patkowska: Przesłanki aktywności politycznej jednostki i jej konsekwencje [The reasons for individual political activity and its consequences] (Poznań 2017), Aktywność polityczna w teorii demokracji - spór o ideat obywatela [Political activity in the theory of democracy - a dispute over the ideal citizen] (Poznan 2018), and the study by Andrzej Antoszewski, Demokracja nieliberalna jako projekt polityczny [Illiberal democracy as a political project] (Warszawa 2018). The empirical data employed to verify the hypotheses posed in this paper was retrieved primarily from the website of the National Electoral Commission (www.pkw.gov.pl), and auxiliary information was obtained from other sources, including the International Institute for Democracy and Electoral Assistance (www.idea.int). The main methods used in the study include the analysis and criticism of literature (sources), the systemic method, and statistical methods.

First, the methodological assumptions of the article are formulated, then the reasons for electoral activity and passivity are discussed and presented in the context of the broader concept of political participation. Next, the results of research into the electoral participation of Polish citizens in the period under analysis are presented. In the discussion of the research problem, the concept of illiberal democracy is addressed, which (along the determinants of the level of political participation identified before) seems to provide the relevant systemic context for the socio-political processes taking place in Poland. The paper ends with conclusions from the conducted study.

\footnotetext{
${ }^{2}$ The article presents the state of law as of March 30, 2020.
} 


\section{The determinants of the level of political participation and electoral activity}

The results of studies on political participation ${ }^{3}$ demonstrate that its level is affected by several groups of factors, such as the political system, historico-cultural experience and the individual properties of people (Skarżyńska, 2005, p. 149). It is an inherent feature of non-democratic systems that they do not permit the alteration of power through elections, which is a typical characteristic of democratic systems. The discussion on the advantages and shortcomings of democracy dates back centuries and has produced various approaches. What seems to be an essential advantage of democracy is that it facilitates the peaceful alternation of power and thus the change of the political (ruling) elite. By this token, the democratic system involves a certain standard of political participation or taking part in politics (Skarżyńska, 2005, p. 150). The dispute concerns the scope of political activity and the question of the expected level of citizens' participation. One end of the continuum is occupied by the advocates of participatory democracy who expect perpetual public involvement in political life, while the other end features the proponents of participation being limited to the election of representatives (supporters of liberal democracy). In the liberal model citizens' political activity "is restricted to the legitimization of representative power by choosing its representatives. One can go as far as to say that citizens' excessive political activity is seen as a threat, especially if it goes beyond a conventional framework" (Pająk-Patkowska, 2018, p. 43). Of course, there are many intermediate solutions between the extremities of the continuum.

Historical and cultural experiences are another factor that influences the level of political participation. Without analyzing this issue in detail, a certain generalization can be made, by claiming that the level of political activity is higher in the states with significant democratic traditions than it is in young democracies (Skarżyńska, 2005, pp. 150-154).

Political activity and passivity are two different outcomes of people's individual characteristics. "When an individual feels no affiliation with the political system, they feel alien in it, they withdraw from political activity, or join in acts of protest" (Skarżyńska, 2005, p. 154).

In terms of one of the forms of conventional political participation, namely elections, the following determinants of the decision to become active or remain passive in elections have been identified:

- "cultural, historical and social traditions which shape standards ("what should be done');

- features of the electoral situation;

- individual socio-demographic and psychological properties" (Skarżyńska, 2005, p. 204).

Krystyna Skarżyńska notes that one's "participation in elections is more likely when an individual is anchored in a culture which generally values electoral participation as an act of legitimizing democratically elected authorities, and places a high value on the ability to influence the shape of authorities. Such attitudes and values result from the broadly understood political socialization [...], which prepares citizens for their extensive participation in political life. In countries with established democratic traditions, where individual influ-

${ }^{3}$ For the purposes of this article, the terms political participation and political activity are treated as being synonymous. 
ence is valued, electoral participation is usually greater than where civic participation is not a standard" (Skarżyńska, 2005, p. 205). Thus cultural, historical and social experiences are clearly the factors that differentiate individual countries in terms of both the broadly understood political participation and one of its forms, namely electoral participation. Countries with longer democratic traditions, in which the value of political activity is passed down from generation to generation, usually have a higher (often significantly higher) voter turnout compared to countries that have only recently started the formation of their democratic political systems. In this context, it is interesting to note that political activity is the essence of political culture, which is created by "values, beliefs, assessments and models of political behavior that make up specific attitudes of individuals and groups towards politics and the political system. Attitudes can be shaped on the basis of smaller or greater knowledge about the features of the regime and can manifest themselves in an active form (various forms of political participation) or a passive form, where reality is assessed without being involved in its change" (Jabłoński, 1998, p. 178).

The formation of political culture is a long process, which is why changes are slow and take decades rather than years. While the implementation of specific legislative changes (e.g. the introduction of free elections) is a relatively easy and speedy process, their internalization by the public requires much longer. Importantly, in the states departing from non-democratic solutions and forming democratic political systems, the negative relationship between the state (government) and the public can pose a considerable challenge. Such a relationship is characteristic of authoritarian or totalitarian systems because non-democratic governments do not treat societies as their partners but are suspicious of them and oppose any forms of autonomous self-organization of society. In other words, the authorities are doing their best to prevent the formation of civil society because such social organization can pose a threat to the authorities. A negative government-citizens relationship diminishes the already low political activity due to the lack of mutual trust. Therefore, states going through the process of political transformation usually have to face high levels of electoral passivity. "In the 1990s in Poland the negative attitude to politicians and politics, seen as a cynical play for power and money, a play in which the honest stand no chance, was associated with political passivity, in particular in the area of conventional participation" (Skarżyńska, 2005, p. 155). This situation seems not to have improved despite the time elapsed, which translates, among other things, into the predominance of negative selection in the political elites. The analysis of the hierarchy of professions enjoying social respect leads to the conclusion that those related to politics are at the bottom end of this ranking (CBOS, 2013, 2019).

The results of the Democracy Index 2019 demonstrate that the highest level of political participation ${ }^{4}$ exists in North America and Western Europe, that is, in the regions where states with the oldest democratic traditions prevail. Another interesting fact is that the majority of full democracies ${ }^{5}$ were also found in these two areas (16 out of

${ }^{4}$ When assessing political participation, the following indices, among others, are taken into consideration: voter turnout, civil involvement in politics, government endeavors to promote political participation (for more see: The Economist, pp. 58-60).

${ }^{5}$ In this study I refer to the classification of political regimes developed by The Economist Intelligence Unit, which distinguishes full democracies, flawed democracies, hybrid regimes and authoritarian regimes (The Economist). 
22 in 2019). The political participation ratio was considerably lower in Eastern European countries, that is in the region with considerably younger democratic traditions (no state was classified as a full democracy ${ }^{6}$ ). The situation in all the regions investigated in the study is shown in Figure 1.

Figure 1. The level of political participation by region

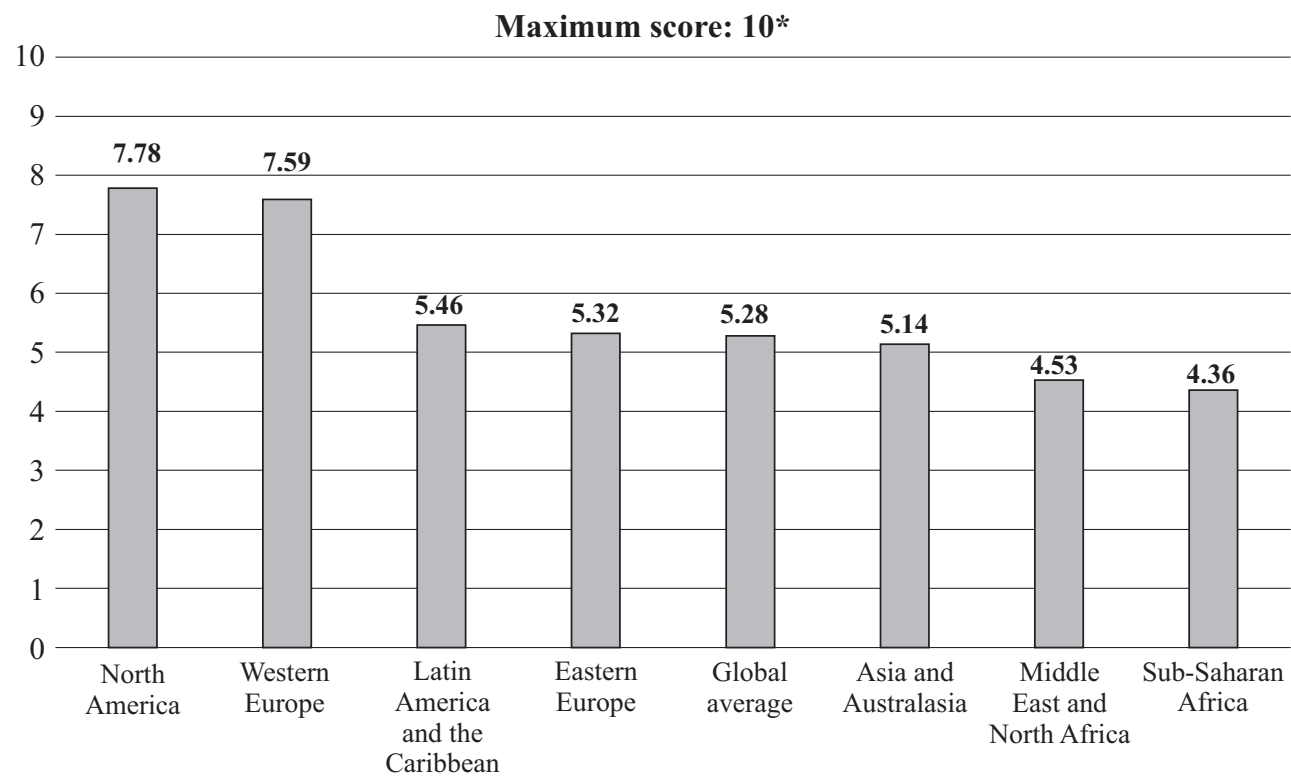

* Every category in the Democracy Index is rated from 0 (the lowest) to 10 (the highest).

Source: The author's own elaboration, based on: The Economist Intelligence Unit, Democracy Index 2019, passim, https://www.eiu.com/topic/democracy-index, 17.04.2020.

In his comparison of political participation, Dieter Nohlen observed that "the distinction between old and new democracies represents fundamentally different social conditions which have a profound impact not only on the development of a democracy, but also on the meaning of elections and electoral participation" (Nohlen, 2002, p. 15). He identified four general variables which make a difference in voter participation (Nohlen, 2002, pp. 15-16):

- levels of social equality - relatively high levels of social inequality which are characteristic of new democracies are unfavorable from the point of view of political participation;

- the governmental or societal focus of the political culture - in new democracies the political culture has a governmental focus;

- new democracies are struggling with a lack of democratic governance and weakness in the rule of law;

- confidence in political institutions - new democracies are characterized by a comparatively strong distrust in political institutions.

${ }^{6}$ In the 28 Eastern European states there were no full democracies, twelve flawed democracies, 9 hybrid regimes and 7 authoritarian regimes (The Economist, p. 23). 
Another group of factors that have a bearing on the level of voter turnout involve the features of the electoral situation, that is, all the elements that arouse public interest and inspire people's electoral activity (Skarżyńska, 2005, p. 208). The following elements fall under this category (Skarżyńska, 2005, pp. 208-212):

- compulsory voting;

- alternative voting methods;

- the stability of electoral law, as well as the level of its understanding and acceptance by the public;

- the type of electoral law;

- clarity regarding what is happening on the pre-election political scene;

- the validity of a particular electoral procedure;

- the possibility of achieving a profound political change due to elections.

Political activity also depends on individual socio-demographic features, such as gender, age, place of residence, education, professional and material status, involvement in the work of foundations, associations and other formalized establishments (Skarżyńska, 2005 , p. 212). Individual psychological characteristics are also important, including the assessment of one's own political efficiency, trust in politics and the internalization of the value constituted by electoral participation (Skarżyńska, 2005, p. 215).

Beata Pająk-Patkowska emphasizes that "in most countries women tend to vote in elections slightly less frequently than men. However, the importance of gender is currently losing importance and the level of voter turnout is becoming equal in both genders" (PająkPatkowska, 2017, p. 13). While the differences concerning active electoral law are decreasing (and sometimes disappearing altogether), differences persist in passive electoral law, hence mechanisms such as quotas and electoral parities are introduced to increase the participation of women in political elites (Pająk-Patkowska, 2019, pp. 21-44). As of October 1,2019 , on average women accounted for $24.5 \%$ of the members of national parliaments (Women). As far as age is concerned, "certain relatively permanent relations can be found, such as the fact that the most politically active persons, especially in terms of conventional activity, are working-age people in the 35-55 age bracket. The youngest and the oldest are the least active as voters" (Pająk-Patkowska, 2017, p. 15). As concerns other elements of an individual's socio-demographic profile, it should be stressed that "the persons with a higher status - typically the inhabitants of larger towns, better educated and professionally active people with higher incomes - tended to be more active both in the conventional and nonconventional modes than the inhabitants of smaller towns with lower education, professionally passive and with lower incomes" (Pająk-Patkowska, 2017, pp. 15-16).

Another interesting element in this context concerns the role of emotions in political thinking and the influence emotions have on voter turnout. Without delving too deep into this question, it should be highlighted that attitudes to this issue vary. Some point to the negative role of emotions, but there are also voices indicating their positive roles and claiming that people become interested in politics only after it arouses their emotions, making them think about politics, which may translate into higher voter turnout, among other things. In the former case, "emotions are treated in terms of hindrance to the quality and rationality of political thinking” (Skarżyńska, 2005, p. 86). In the latter case, it is argued that "common people do not think about politics unless their emotions are aroused" (Skarżyńska, 2005, p. 88). Therefore, "the emotions associated with the can- 
didates and electoral campaign not only increase voter turnout but also motivate people to engage in cognitive activity and learn about candidates" (Skarżyńska, 2005, p. 90).

\section{Voter turnout at the national level in Poland 1990-2019}

Poland is among the countries where voter turnout tends to be low, and - taking a broader perspective - the level of political participation is also comparatively low (López-Pintor, Gratschew, Sullivan, 2002, pp. 75-91). After World War Two, Poles could not vote in free elections for decades. The establishment of free elections was a difficult and complex process, but "examining voter turnout in successive elections at present can lead to the conclusion that their importance for democracy is underestimated" nevertheless (Stępien-Załucka, 2017, p. 223). Even the first partially free election ("the contractual election") after World War Two, conducted in 1989, did not mobilize the general public and result in high electoral participation. While it is true that voter turnout exceeded $62 \%$ in this election, this also means that nearly $40 \%$ of Poles did not take part in this historical voting. Even at the very beginning of the political transformation a significant proportion of people chose electoral passivity instead of participation. Reviewing the statistics from successive votes, it can be noted that voter turnout exceeded that recorded in 1989 only once, in the 1995 presidential elections. It can therefore be posited that voter turnout slightly over $60 \%$ constitutes a cap on the electoral activity of Poles at the national level. It is worth mentioning here that only $58.85 \%$ of eligible voters took part in the $2003 \mathrm{EU}$ referendum, in spite of its essential importance and a range of efforts launched to encourage voter participation (Rachwał, 2010, pp. 182-187). In the remaining national referenda conducted during the political transformation, voter turnout did not exceed 50\%, and was actually nowhere near this level in the 2015 referendum, when voter turnout was in single digits (Rachwał, 2016, pp. 174-175).

Examining the statistics in figures 2, 3 and 4 it transpires that the highest level of electoral participation was recorded in presidential elections (nearly $57 \%$ on average), followed by parliamentary elections (nearly $50 \%$ ), and it was the lowest in the elections to the European Parliament (nearly 29\%). Skipping the 2019 statistics for a moment, the EP election was clearly treated as a "second-order elections" and voter turnout did not exceed 25\% (Rachwał, 2017b, pp. 61-73). Electoral participation at the national level in Poland in the period under analysis ranged from $21 \%$ to $68 \%$, with voter turnout being the lowest in the elections to the European Parliament and the highest in presidential elections.

Undertaking this study, the research problem was formulated with reference to the determinants of the clearly increased electoral activity of Polish citizens in 2019. The highest level of electoral participation over the period under analysis was recorded in the elections to both chambers of the national parliament and to the European Parliament. With reference to the research problem formulated in the introduction, it can be repeated that the following groups of factors affect the levels of electoral participation: tradition-related determinants, the features of the electoral situation, the characteristics of individuals, and the level of political emotions. The analysis conducted for the purpose of this study makes it possible to identify four basic factors that can explain the research problem. Since they are associated with the electoral situation and emotions, these topics should be further elaborated on. 
Figure 2. Voter turnout in presidential elections in Poland (percentage)

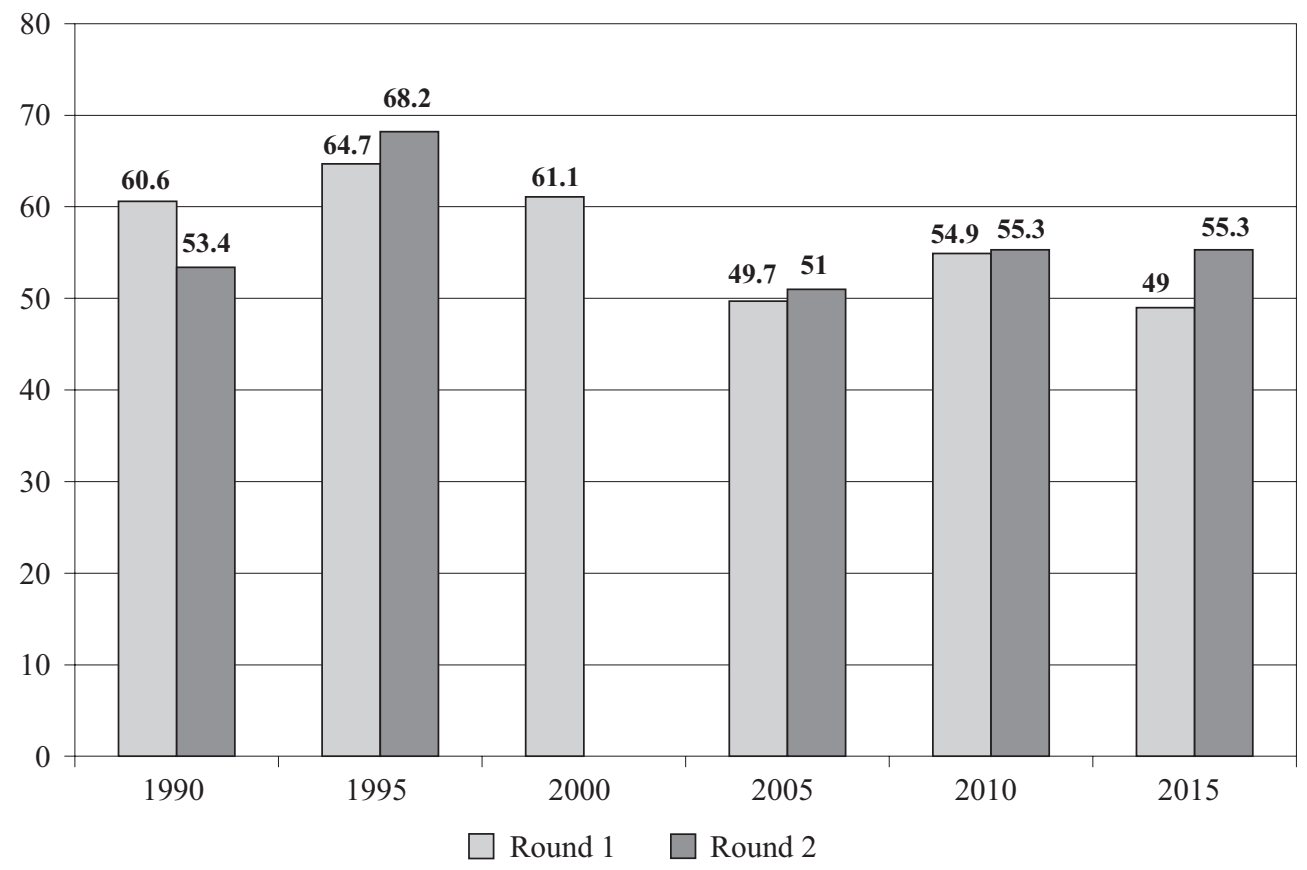

Source: The author's own elaboration, based on the statistics of the National Electoral Commission: Wybory Prezydenta Rzeczypospolitej Polskiej, pkw.gov.pl/313_Wybory_Prezydenta_Rzeczypospolitej_Polskiej, 31.01.2020; Leksykon politologii, eds. A. Antoszewski, R. Herbut, Wrocław 2002, pp. 556-558.

Figure 3. Voter turnout in parliamentary elections (Sejm and Senate) (percentage)

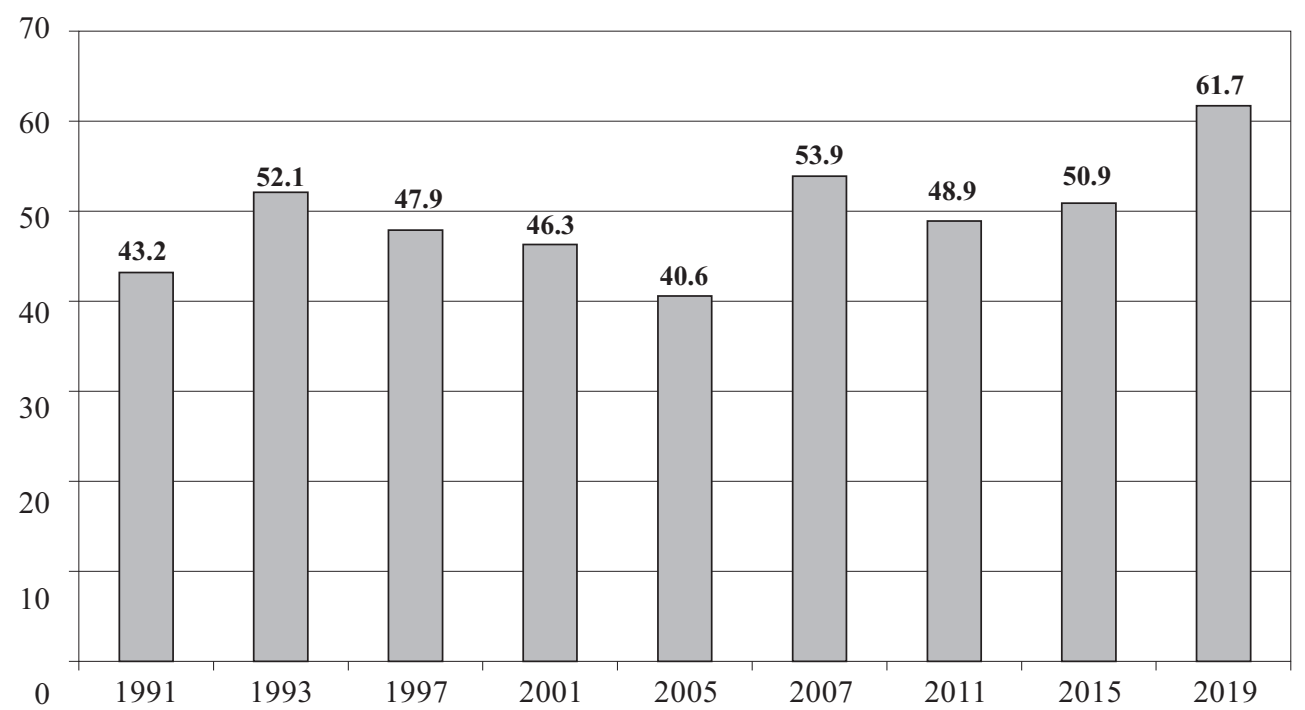

Source: The author's own elaboration, based on the statistics of the National Electoral Commission: Wybory do Sejmu i do Senatu, www.pkw.gov.pl/315_Wybory_do_Sejmu_i_do_Senatu, 31.01.2020; Leksykon politologii, eds. A. Antoszewski, R. Herbut, Wrocław 2002, pp. 521-524. 
Figure 4. Voter turnout in Poland in elections to the European Parliament (percentage)

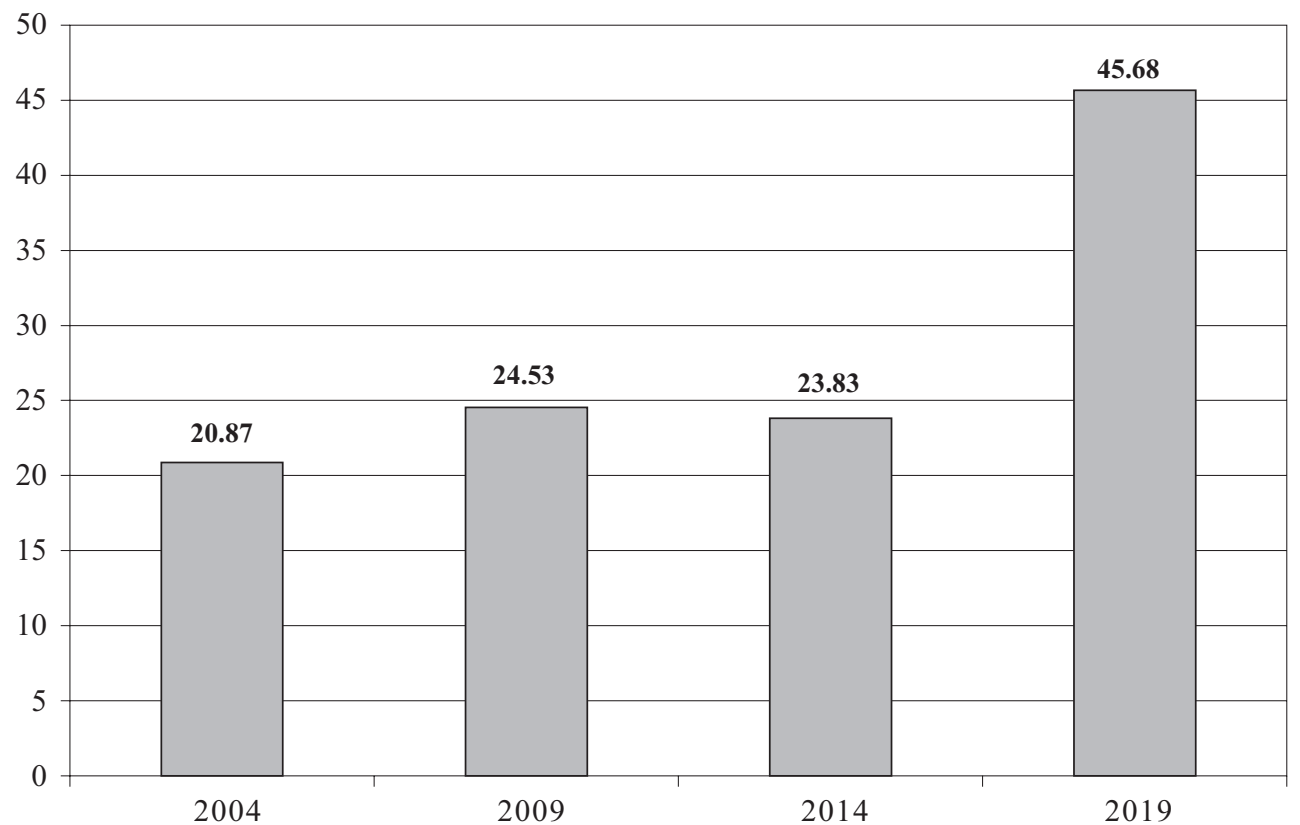

Source: The author's own elaboration, based on the statistics of the National Electoral Commission: Wybory do Parlamentu Europejskiego, www.pkw.gov.pl/316_Wybory_do_Parlamentu_Europejskiego, 30.01.2020.

After Law and Justice ${ }^{7}$ came to power in 2015, the greatest changes ensued in terms of the features of the electoral situation, which translated into a sharp increase in political emotions. It is worth recalling at this point that Law and Justice put forward and then began to rapidly implement a range of transformations which, when combined, translates into a new vision of the state. The changes proposed are not so much reforms of the functioning social system, but rather a far-reaching transformation of the political system, among other things. Although the image of the Fourth Republic of Poland ${ }^{8}$ is not publicly emphasized in this term of the Law and Justice government, it marks a return to the slogans promoted in the period of their former government (2005-2007). The very use of the numeral implies that what is at stake is not the continuation of the state constructed as a result of the systemic transformation started in 1989, but rather the construction of a state founded on profoundly different premises. Writing the justification for a draft constitution of the Fourth Republic, Law and Justice stressed that their "draft breaks with the post-communist double identity of the Third Republic, with solutions which are a muddle of the traditions of the independent state of Poland and the burden of the Polish People's Republic. [...] So far, Polish politics has been dominated by the voices of the defenders of the current constitution for selfish reasons. That is why the post-communist

7 The article consistently refers to the Law and Justice political party but the Electoral Committee of Law and Justice in 2015 included also the representatives of the political parties of Jarosław Gowin and Zbigniew Ziobro. The same holds true also for the 2019 elections (to the European Parliament and both chambers of the Polish parliament).

${ }^{8}$ For the purposes of this paper, the terms Fourth Republic and illiberal democracy (illiberal democracy model) are used interchangeably. 
empire has expanded at the expense of the good of Poland. Once our draft constitution is announced, the constitutional debate has to profoundly change its nature. We are presenting a holistic vision of the political system and a complete draft of the Basic Law which expresses our aspiration to build the Fourth Republic" (Konstytucja, 2005). It can be noted in passing that in the Polish tradition, successive ordinal numbers reflected the periods of the state's sovereign existence, while the solution suggested by Law and Justice was related to the change of the political system. The politicians who advocate the transition from the Third to the Fourth Republic "make a clear reference to French political terminology [...]. However, the Polish tradition of naming distinguishes three successive Republics on a completely different basis than the French tradition" (Liczebniki).

The vision of the Fourth Republic and successive stages of its implementation increasingly diverted from the direction of the state hitherto. A question arises here of what the Fourth Republic actually is. "From the point of view of the integrational concept of sociopolitical divisions, the name Fourth Republic can be treated as a model of the attitude which contains all the dimensions of divisions. In the area of history, the Fourth Republic means the construction of a de-communized state, thereby emphasizing the significance of the conflict between the post-communist and post-Solidarity orientations. In terms of the economy, the Fourth Republic is a state of solidarity which opposes the liberalization of the economy. In the area of culture, the Fourth Republic is axiologically traditional, driven by the Christian value system and it opposes post-materialism. As regards politics, the Fourth Republic is a strong state where power is centralized to quite a large degree. Finally, in the national-European context, the Fourth Republic cultivates the national identity of Poles and consolidates the strong position of Poland in the international arena even at the expense of losing other states' sympathy" (Figiel, 2009, p. 167).

A brief outlining of the historical background seems indispensable for the full understanding of the socio-political situation after Law and Justice came to power in 2015. This far-reaching transformation has won the support of quite a numerous group of advocates (beneficiaries of the system), but quite a huge group of its opponents have voiced their protests in conventional and unconventional forms (e.g. numerous demonstrations). This has considerably fueled political emotions and polarized the political scene. "From the perspective of illiberal democracy, politics is a zero sum game conducted in the conditions of growing polarization" (Antoszewski, 2018, p. 59).

The issue of socio-political divisions should be addressed in this context. Sharp divisions do not seem to be the feature of the present only. Looking back at the history of Poland in the twentieth century alone, such divisions can be repeatedly seen, as pointedly explained by Witold Pilecki. "Therefore, every day, Poles had to be shown a pile of Polish corpses to make peace with each other and to decide that there is a rationale greater than the differences and enmity between them, namely a concord and united front against the common enemy, more than one of whom we always had. So the rationale of concord and the rationale of the united front has always existed and has always been in opposition to what we did in Poland - perpetual pettifogging and being at loggerheads with one another in parliament" (Raport).

Successive changes introduced in the judiciary, public administration, public media, the system of higher education, the reform of education, changes to the retirement system and the expansion of the social function of the state constitute only some of the ac- 
tivities implemented after Law and Justice came to power in 2015. Examining solely the aspects related to the political system, it should be emphasized that these steps departed from building liberal democracy in favor of the model of illiberal democracy. This is evidenced, inter alia, by changes implemented in the area of the judiciary, from the Constitutional Tribunal through a variety of other changes to the Supreme Court. The common denominator for all these activities was the removal of the restrictions imposed on the legislative and executive powers under the principle of the separation of powers in the model of liberal democracy. The term liberal democracy means the union of democracy (majority rule) and liberalism (individual freedom and the need to limit the arbitrariness of the government) (Antoszewski, 2018, p. 51). "The primary value in democracy is the power of the people and their participation in government, while in liberalism, it is human rights and powers and constitutional regulations" (Rozen, 2018, p. 119).

The vision of the state implemented under the Fourth Republic began to be defined as illiberal democracy. Without delving into the complex relation between democracy and liberalism, it should be stressed that illiberal democracy is about reducing democracy "to holding competitive elections resulting in the unconditional domination of the majority" (Antoszewski, 2018, p. 51). Therefore, the powers of institutions that can limit the victorious parliamentary majority are minimized. There are many examples of this, but it is particularly worth noting that the principles of operation of the Constitutional Tribunal were changed shortly after the 2015 election. Why did this judicial authority become the object of dispute right away? The answer to that can be found in the Constitution of Poland: "The Constitutional Tribunal shall adjudicate regarding the following matters: the conformity of statutes and international agreements to the Constitution" (Konstytucja, 1997, Art. 188). This means that the Constitutional Tribunal may rule that the law passed by the parliamentary majority is unconstitutional, which results in such a law becoming invalid, but such activity defies the principles of illiberal democracy. ${ }^{9}$ The implementation of this variant of democracy requires "specific modifications of the structure of the political system. They consist primarily in strengthening the tendency to concentrate and centralize power, which means rejecting consensual democracy and adopting the majority model as the only variation" (Antoszewski, 2018, p. 59).

The changes introduced after 2015 concerned the political system, but the concept of the Fourth Republic entails more than the social space discussed above. With reference to the terminology proposed, the name Fourth Republic applies to changes introduced to the areas of history, economy, axiology and the national/European aspect. All these processes translate into considerable changes in the social structure. The possibilities of promotion are opening to some people while other people are facing serious obstacles in this field. The overall outcome of these changes is conducive to political polarization and, by this token, to electoral polarization. As a consequence, the political stage is becoming clearer for voters. The socio-political divisions which have been introduced and highlighted are making the pre-electoral situation more transparent,

9 "Judgments of the Constitutional Tribunal shall be of universally binding application and shall be final. [...] A judgment of the Constitutional Tribunal shall take effect from the day of its publication, however, the Constitutional Tribunal may specify another date for the end of the binding force of a normative act. Such time period may not exceed 18 months in relation to a statute or 12 months in relation to any other normative act" (Konstytucja, 1997, Art. 190). 
and voters can find their way around electoral reality, which is typically much more complex. In illiberal democracy, "political competition involves primarily the political parties which opt for liberal democracy or are against it" (Antoszewski, 2018, p. 61). We are thus dealing with an almost dichotomous division of the political stage, which was particularly visible in the 2019 elections to the European Parliament where Law and Justice (illiberal democracy) was competing against the European Coalition composed of the Civic Platform, the Polish People's Party, the Democratic Left Alliance, .$N$ and the Greens (liberal democracy). While nine electoral committees took part in the EP elections in Poland, the main division line separated the two groups above, which collectively garnered nearly $84 \%$ of votes (Wybory_1). The electoral stage was different in the 2019 elections to both chambers of the national parliament, but the main division remained unchanged: the choice between liberal or illiberal democracy. That is why the 2019 election could have brought a significant change to the political stage then (a feature of the electoral situation).

Due to these processes, the 2019 election was actually a plebiscite ${ }^{10}$ mobilizing both the supporters and opponents of Law and Justice. We witnessed considerable social mobilization with the conventional participation of Polish citizens almost reaching the upper limit for elections to the national parliament. Voter turnout at the level of over $60 \%$ is a very high result in Poland and provides evidence of an exceptional electoral situation. The 2019 election was a vote for or against the government, or - taking a broader perspective - a choice between liberal or illiberal democracy.

\section{Conclusions}

Voter turnout at the national level in Poland is among the lowest in Europe. However, Law and Justice being in power brings about the increased electoral mobilization of Polish citizens. The premise adopted in this paper is confirmed by the 2005-2007 period (voter turnout in the 2007 parliamentary elections was higher than that in 2005, by 13 percentage points). During the next term of Law and Justice government (20152019) the electoral activity of Poles reached the highest level in the period under analysis (1990-2019). The question of the reasons explaining this trend arises.

In an attempt to address the research problem it can be suggested that the increased voter turnout in 2019 was caused by the factors identified as features of the electoral situation. To be more precise, the following issues seemed to be of utmost importance: (1) the polarization of the political scene, which translated into the polarization of the electoral scene; (2) a generally clear pre-electoral situation (as an outcome of (1)); (3) a high level of political emotions; and (4) the high importance of the election, in which a considerable change to the political stage could have ensued (supporting the model of liberal democracy vs. the model of illiberal democracy). Thus the 2019 election was not about making a choice within the framework of liberal democracy (the election of people

${ }^{10}$ Plebiscite "can mean voting (e.g. in an election) where the choice is limited to two political parties, blocs, candidates or governments (e.g. the election to both chambers of the Polish parliament in June 1989 was such a plebiscite)" (Polskie, p. 135). The 2019 election seems to meet the conditions for a plebiscite thus understood. 
who would perform specific political roles within the stable model of liberal democracy) but was actually a vote for a defined model of democracy.

\section{Bibliography}

Antoszewski A. (2018), Demokracja nieliberalna jako projekt polityczny, in: Zmierzch demokracji nieliberalnej?, eds. K. A. Wojtaszczyk, P. Stawarz, J. Wiśniewska-Grzelak, Warszawa.

CBOS (2013), Prestiż zawodów, Komunikat z badań, BS/164/2013, https://www.cbos.pl/SPISKOM. POL/2013/K_164_13.PDF, 20.04.2020.

CBOS (2019), Które zawody poważamy?, Komunikat z badań, nr 157/2019, https://www.cbos.pl/SPISKOM.POL/2019/K_157_19.PDF, 20.04.2020.

Figiel A. (2009), Języki IV RP. Podziały społeczno-polityczne w dyskursie polityki, Poznań, https:// repozytorium.amu.edu.pl/bitstream/10593/4781/4/Agnieszka_Figiel.pdf, 24.04.2020.

Jabłoński A. W. (1998), Kultura polityczna i jej przemiany, in: Studia z teorii polityki, vol. II, eds. A. W. Jabłoński, L. Sobkowiak, Wrocław.

Konstytucja (1997): Konstytucja Rzeczypospolitej Polskiej z dnia 2 kwietnia 1997 r., Dz. U. 1997, $\mathrm{Nr} 78$, poz. 483, z późn. zm.

Konstytucja (2005): Konstytucja Rzeczypospolitej Polskiej z 2005 r., Projekt Prawa i Sprawiedliwości, https://oko.press/images/2017/10/PiS-projekt-konstytucji-2005.pdf, 24.04.2020.

Leksykon politologii (2002), eds. A. Antoszewski, R. Herbut, Wrocław.

Liczebniki ustrojowe, "Rzeczpospolita” z 16 sierpnia 2005 roku, https://archiwum.rp.pl/artykul/564043Liczebniki-ustrojowe.html, 25.04.2020.

López-Pintor R., Gratschew M., Sullivan K. (2002), Voter Turnout Rates from a Comparative Perspective, in: Voter Turnout since 1945. A Global Report, International IDEA 2002, https://www. idea.int/sites/default/files/publications/voter-turnout-since-1945.pdf, 26.04.2020.

Nohlen D. (2002), Political Participation in New and Old Democracies, in: Voter Turnout since 1945. A Global Report, International IDEA 2002, https://www.idea.int/sites/default/files/publications/voter-turnout-since-1945.pdf, 20.04.2020.

Pająk-Patkowska B. (2017), Przesłanki aktywności politycznej jednostki i jej konsekwencje, in: Uwarunkowania i mechanizmy partycypacji politycznej, ed. M. Rachwał, Poznań.

Pająk-Patkowska B. (2018), Aktywność polityczna w teorii demokracji - spór o ideat obywatela, in: Aktywność polityczna i jej przejawy we współczesnych państwach, eds. J. Jakubowski, B. PająkPatkowska, Poznań.

Pająk-Patkowska B. (2019), Uwarunkowania obecności i aktywności kobiet w Sejmie RP w latach 1989-2018, Poznań.

Państwowa Komisja Wyborcza, www.pkw.gov.pl, 2020.

Polskie prawo konstytucyjne (2000), ed. W. Skrzydło, Lublin.

Rachwał M. (2010), Demokracja bezpośrednia w procesie kształtowania się spoleczeństwa obywatelskiego w Polsce, Warszawa.

Rachwał M. (2012), Przymus wyborczy a legitymizacja władzy politycznej, "Środkowoeuropejskie Studia Polityczne", no. 4.

Rachwat M. (2016), The Polish model of democracy, in: Hungary and Poland in Times of Political Transition. Selected Issues, eds. B. Pająk-Patkowska, M. Rachwał, Poznań.

Rachwał M. (2017a), Wybory we wspótczesnym państwie demokratycznym, [in:] Uwarunkowania i mechanizmy partycypacji politycznej, ed. M. Rachwał, Poznań.

Rachwał M. (2017b), Znikajacy wyborcy - partycypacja w wyborach do Parlamentu Europejskiego, in: Współczesne oblicza władzy politycznej. Wybrane zagadnienia, ed. M. Rachwał, Poznań. 
Raport Witolda, http://rtmpilecki.eu/wp-content/uploads/2017/08/RAPORT-WITOLDA-PILECKIEGO.pdf, 24.04.2020.

Rozen Ł. (2018), Liberalizm i demokracja jako fundamentalny dylemat współczesnej polityki, in: Zmierzch demokracji nieliberalnej?, eds. K. A. Wojtaszczyk, P. Stawarz, J. Wiśniewska-Grzelak, Warszawa.

Skarżyńska K. (2002), Aktywność i bierność polityczna, in: Podstawy psychologii politycznej, ed. K. Skarżyńska, Poznań.

Skarżyńska K. (2005), Człowiek a polityka. Zarys psychologii politycznej, Warszawa.

Sokala A., Michalak B., Uziębło P. (2013), Leksykon prawa wyborczego i referendalnego oraz systemów wyborczych, Warszawa.

Stępień-Załucka B. (2017), E-voting a Konstytucja RP, in: Dwadzieścia lat obowiązywania Konstytucji RP. Polska myśl konstytucyjna a międzynarodowe standardy demokratyczne, eds. J. Jaskiernia, K. Spryszak, Torun.

The Economist Intelligence Unit, Democracy Index 2019, https://www.eiu.com/topic/democracy-index, 17.04.2020.

The International Institute for Democracy and Electoral Assistance, www.idea.int, 2020.

Ustawa z dnia 5 stycznia 2011 r. Kodeks wyborczy, t.j. Dz. U. 2019, poz. 684, z późn. zm.

Women in National Parliaments, http://archive.ipu.org/wmn-e/arc/world011019.htm, 02.02.2020.

Wybory do Parlamentu Europejskiego, www.pkw.gov.p1/316_Wybory_do_Parlamentu_Europejskiego, 30.01.2020.

Wybory do Sejmu i do Senatu, www.pkw.gov.p1/315_Wybory_do_Sejmu_i_do_Senatu, 31.01.2020.

Wybory Prezydenta Rzeczypospolitej Polskiej, pkw.gov.pl/313_Wybory_Prezydenta_Rzeczypospolitej_Polskiej, 31.01.2020.

Wybory_1: Wybory do Parlamentu Europejskiego 2019, https://pe2019.pkw.gov.pl/pe2019/pl/wyniki/ pl, 25.04.2020.

\section{Frekwencja wyborcza w Polsce na poziomie ogólnokrajowym - wybrane aspekty zagadnienia}

\section{Streszczenie}

Przedmiotem artykułu jest zagadnienie frekwencji wyborczej w Polsce na poziomie ogólnokrajowym w latach 1990-2019. W szczególności autor skupił uwagę na roku 2019, gdyż zanotowano wówczas najwyższą frekwencję w wyborach parlamentarnych w analizowanym okresie. Celem badań było ustalenie przesłanek, które miały wpływ na wskazaną sytuację, na wzrost aktywności wyborczej obywateli RP. Przeprowadzona analiza skłania do wniosku, iż po przejęciu władzy przez Prawo i Sprawiedliwość w 2015 roku doszło do istotnych modyfikacji systemu społecznego, w tym politycznego, co przyczyniło się do zmiany wybranych cech sytuacji wyborczej i podwyższenia poziomu emocji politycznych. Konsekwencją był znaczny wzrost frekwencji wyborczej w 2019 roku, gdy odbyły się wybory do Parlamentu Europejskiego, jak również do Sejmu i Senatu.

Podczas badań zastosowanie znalazły: metoda analizy i krytyki piśmiennictwa (źródeł), metoda systemowa, metody statystyczne.

Słowa kluczowe: demokracja, demokracja nieliberalna, partycypacja polityczna, wybory, frekwencja wyborcza 